\section{Incidence of thyroid disease associated with oral contraceptives}

Cell-mediated immunosuppression in pregnancy and in women taking oral contraceptives has been described. ${ }^{12}$ Temporary remission of autoimmune thyroid disease with postpartum recurrence has also been reported associated with the gradual reduction of serum antithyroid antibody titres as the pregnancy progressed, followed by a postpartum increase reaching a peak three to four months after delivery. ${ }^{3}$

\section{Study and results}

Thyroid diseases were analysed as part of a continuing major prospective survey of oral contraceptives. The study began in 1968. About 23000 women currently taking a contraceptive pill and a similar number of controls who had never taken an oral contraceptive were recruited by 1400 general practitioners over a period of 14 months. Observations of subsequent morbidity and other relevant data of this population formed the basis for our analyses. The design of the study and the interpretation of the findings have been described elsewhere. ${ }^{4}$

The main findings are shown in the table. Because of the close interrelationship of thyroid disorders we analysed only the frequency of reporting of the first diagnosis during the study of any thyroid disease in one patient. Cases first diagnosed during pregnancy were excluded together with the associated periods of observations. Patients were categorised according to their contraceptive status at the time of diagnosis as (1) takers (those currently taking an oral contraceptive who had had no break in use longer than one cycle); (2) ex-takers (those who had formerly used oral contraceptives); and (3) controls (those who had never used oral contraceptives). All three clinical groups of thyroid disease were reported less frequently in takers than in controls. In patients with euthyroid swelling the rate in takers was $69 \%$ of that in controls, and the proportions for thyrotoxicosis and myxoedema were $71 \%$ and $57 \%$ respectively. Although these differences taken separately do not reach statistical significance, the frequency of reporting in takers was consistently materially less than in controls. When the subcategories are combined the risk ratio of 0.68 becomes highly significant $(\mathbf{P}<0.01 ; 95 \%$ confidence limits 0.52 to 0.85 ). An important finding was that the rates for thyroid disease in ex-takers did not differ from controls. The frequency of reporting of thyroid disease showed no correlation with age, parity, cigarette consumption, or social class in any of the contraceptive categories, and reporting rates did not correlate with oestrogen or progestogen dosage or with the duration of use of oral contraceptives.

\section{Comment}

These results suggest that oral contraceptives exert a protective effect against thyroid disease. In our interim report ${ }^{4}$ we assessed the probable biases in a prospective study of this type. Selection bias was substantially avoided by excluding all women who had had the disease before recruitment. Other forms of bias generally operate in the one direction, giving an estimated $20 \%$ overreporting in the takers and a tendency to exaggerate adverse reactions to oral contraceptives and underassess beneficial effects. Our findings of a higher rate of reporting of thyroid disease in controls than takers is contrary to the expected effect of these biases. The finding that the frequency of thyroid disease in ex-takers is not materially different from the controls suggests that there is no residual protective effect against thyroid disease after the contraceptive has been stopped. Our observations suggest that the effect of oral contraceptives on thyroid disease may be associated with preventing or retarding autoimmune processes. The reduced incidence of rheumatoid arthritis ${ }^{5}$ in oral contraceptive takers probably has a similar mechanism. In absolute terms the protective effect against thyroid disease would be as small as 1 in 1600 oral contraceptive users a year. The observation, however, may contribute to an understanding of the mechanism of action of oral contraceptives and the aetiology of thyroid disease.

${ }^{1}$ Barnes, E W, et al, Lancet, 1974, 1, 898.

${ }^{2}$ Hill, C A St, Finn, R, and Denye, V, British Medical fournal, 1973, 3, 513.

${ }^{3}$ Amino, N, Kuro, R, and Tanizawa, O, Clinical Experimental Immunology, $1978,31,30$

${ }^{4}$ Royal College of General Practitioners, Oral Contraceptives and Health. London, Pitman Medical, 1974.

${ }^{5}$ Royal College of General Practitioners Oral Contraception Study, Lancet, $1978,1,569$.

(Accepted 20 September 1978)

Royal College of General Practitioners Oral Contraception Study, 8 Barlow Moor Road, Manchester M20 0TR

PETER FRANK, MD, FRCGP, deputy director

CLIFFORD R KAY, CBE, MD, FRCGP, director

\section{Uneventful pregnancy after Wilms's tumour}

Pregnancy after successful treatment for Wilms's tumour is rare; we found only one such case reported from California. We describe here another patient managed at the City of London Maternity Hospital who had had a Wilms's tumour in childhood.

\section{Case report}

This 18-year-old, single, West Indian Negro primigravida had her last menstrual period in May 1975 and was seen in the ante-natal clinic in January 1976 in the 36 th week of gestation. She had had no previous antenatal care.

Her history showed that she had been treated for Wilms's tumour of her right kidney. In 1970, when she was 12, she was admitted to Queen Elizabeth Hospital for Children, London, with a mass on her right flank, and the right kidney was removed. A tumour weighing $1 \mathrm{~kg}$ was found, which was shown to be a nephroblastoma. There was no spread beyond the kidney and no obvious lymph node or renal vein metastases. After operation she was given a course of actinomycin D followed by cobalt teletherapy at St Bartholomew's Hospital. A mid-plane dose of 3500 rads was given over five weeks to the right renal bed and para-aortic nodes. No other chemotherapy was given, and she subsequently remained well.

On booking into our unit she appeared to be a well developed, healthy teenager. She was $167.6 \mathrm{~cm}$ tall, weighed $56.7 \mathrm{~kg}$, and had blood pressure of $105 / 60 \mathrm{~mm} \mathrm{Hg}$ and pulse rate of 76 beats/min. A nephrectomy scar was present. The size of her uterus corresponded to the period of amenorrhoea.

First diagnoses of any thyroid disease by oral contraceptive use (standardised for age, cigarette consumption, parity, and social class)

\begin{tabular}{|c|c|c|c|c|c|c|c|c|}
\hline \multirow{2}{*}{ International classification of disease category } & \multicolumn{2}{|c|}{ Takers } & \multicolumn{2}{|c|}{ Ex-takers } & \multicolumn{2}{|c|}{ Controls } & \multicolumn{2}{|c|}{$\begin{array}{c}\text { Ratio of standardised } \\
\text { rates }\end{array}$} \\
\hline & $\begin{array}{c}\text { No } \\
\text { observed }\end{array}$ & $\begin{array}{l}\text { Standardised } \\
\text { rate }(T W Y)\end{array}$ & $\begin{array}{c}\text { No } \\
\text { observed }\end{array}$ & $\begin{array}{l}\text { Standardised } \\
\text { rate (TWY) }\end{array}$ & $\begin{array}{c}\text { No } \\
\text { observed }\end{array}$ & $\begin{array}{l}\text { Standardised } \\
\text { rate (TWY) }\end{array}$ & $\begin{array}{l}\text { Takers: } \\
\text { controls }\end{array}$ & $\begin{array}{l}\text { Ex-takers: } \\
\text { controls }\end{array}$ \\
\hline $\begin{array}{l}240,241,245,246 \text { (Benign thyroid swelling (euthyroid)) } \\
242 \text { (Thyrotoxicosis) } \quad . \quad \cdots \\
244 \text { (Myxoedema) }\end{array}$ & $\begin{array}{l}45 \\
29 \\
11 \\
85\end{array}$ & $\begin{array}{l}0 \cdot 68 \\
0 \cdot 44 \\
0 \cdot 17 \\
1 \cdot 30\end{array}$ & $\begin{array}{l}33 \\
24 \\
15 \\
72\end{array}$ & $\begin{array}{l}0 \cdot 80 \\
0 \cdot 57 \\
0 \cdot 35 \\
1 \cdot 72\end{array}$ & $\begin{array}{r}106 \\
67 \\
32 \\
205\end{array}$ & $\begin{array}{l}0 \cdot 98 \\
0 \cdot 63 \\
0 \cdot 30 \\
1 \cdot 90\end{array}$ & $\begin{array}{l}0 \cdot 69 \\
0 \cdot 71 \\
0 \cdot 57 \\
0 \cdot 68 \dagger\end{array}$ & $\begin{array}{l}0 \cdot 81 \\
0 \cdot 90 \\
1 \cdot 17 \\
0 \cdot 91\end{array}$ \\
\hline Periods of observation (women-years) & \multicolumn{2}{|c|}{66787} & \multicolumn{2}{|c|}{40609} & \multicolumn{2}{|c|}{107551} & & \\
\hline
\end{tabular}

TWY $=$ Thousand women-years

†P $<0.01 ; 95 \%$ confidence limits 0.52 to 0.85 . 